\title{
THE ROLE OF RELIGIOUS TOURISM IN SUSTAINABLE DEVELOPMENT IN SAUDI ARABIA: EVIDENCE FROM QUANTILE NON-CAUSALITY TEST
}

\author{
Mohamed Bilel TRIKI * \\ Department of Management, Community College, University of Bisha, \\ P.O. Box 551, Bisha 61922, Saudi Arabia, e-mail: mtriki@ub.edu.sa
}

\begin{abstract}
Citation: Triki, B.T. (2019). THE ROLE OF RELIGIOUS TOURISM IN SUSTAINABLE DEVELOPMENT IN SAUDI ARABIA: EVIDENCE FROM QUANTILE NON-CAUSALITY TEST. GeoJournal of Tourism and Geosites, 27(4), 1321-1333. https://doi.org/10.30892/gtg.27417-436
\end{abstract}

\begin{abstract}
This paper empirically examines the role of religious tourism in sustainable development to the projection of Saudi Arabia 2030. This study observes the causal relationship between hajj pilgrims and economic growth in the KSA by conducting a quantile Granger non-causality test. We show that the causal relationship between hajj pilgrims and economic growth strengthens when a quantile Granger non-causality test of Chuang et al. (2009) is considered. This finding implies that the hajj pilgrims could provide the incremental predictability for the sustainable development in KSA, and hence, results from linear Granger causality tests cannot be considered robust.
\end{abstract}

Key words: Religious tourism; Economic growth; causality in quantiles; nonlinear dependence; development of the Saudi Arabia territory

\section{INTRODUCTION}

The primary form of tourism is the religious tourism, and the religious pilgrimage dates since the dawn of human history. A pilgrimage has been defined as, "A journey resulting from religious causes, externally to a holy site, and internally for spiritual purposes and internal understanding" by Barber (1993). In addition to its spiritual dimension, 'religious tourism' also has a 'cultural aspect' exerted by the attraction of its architectural, decorative and historical heritage. So, there is an appearance of experience from the pilgrimage way, as cultural heritage attraction, in observation of cultural tourism, training to consume experiences. Religion, by means of a tourist experience, grows into part of the representative economy. Therefore, the experience with tourist fascinations derived from the pilgrimage ways has been broadly developed in form of cultural tourism in our time. These tourist fascinations are also identified as cultural heritage attractions, running as the travel motivations of tourist. On other hand, the religious centres become important parts of some economic circles, like in the western

\footnotetext{
* Corresponding author
} 
world, cities such as Jerusalem, Rome, Mecca and Madinah which stay to attract a big number of visitors on a yearly basis. Nowadays, pilgrimage is defined another way, it can be measured a traditional religious or modern secular journey. Digance (2003) presents the singularity of pilgrimage as resurgence throughout the world with venerable memorials still attracting those in search of spiritual realization. However, the latest works presented by Timothy \& Olsen (2006) on pilgrimage and religious tourism is motionless fragmented and lacks synthesis and universal conceptualization.

In contemporary years, though, religious travel and tourism has settled into a much larger and more segmented market. According to the Organization for Economic Cooperation and Development (OECD) and the World Tourism Organization (UNWTO), cultural and heritage travel in 2017 represented $45 \%$ of all international tourism, compared to $37 \%$ in 1995. According to the World Tourism Organization, 37\% of international travel is related to cultural tourism in which religious and spiritual aspects play an important role. This form of tourism affects most sectors of the economy. The major objective of the religious tourism is a visitation to a specific holy destination. Religious travel can be the principal reason for a trip but it can also be part of a trip and provide a destination with supplementary attractions.

In several countries, religious tourism is one of the greatest essential and ever growing industries in the western world which creates jobs and revenues. The sacred places situated in certain countries offer a specific occasion to tourism industry to develop toward a sound direction and in a maintainable way. In this reverence, Saudi Arabia has an exceptional location for having Mecca and Madinah in addition to other sacred and historical sites. Nevertheless, preceding studies have given less consideration to the economic aspect of Hajj pilgrimage. To study the Hajj duty from the economic perspective, this work observes the predictability of the non-oil-based Gross Domestic Product (GDP) growth of Saudi Arabia based on the growing number of pilgrims at the three latest decades. In the projection 2030 of Saudi Arabia, the kingdom of Saudi Arabia (KSA) needs to look for other source of non-oil-based Gross Domestic Product (GDP) or to differentiate source of GDP. Indeed, the petroleum sector accounts for approximately 86\% of budget revenues, 41\% of GDP, and 91\% of export earnings in 2016.

So, the interest of Saudi Arabia is to diversify its economy. Indeed, oil prices are experiencing a sharp decline, the largest in 10 years. While it seemed that "the equilibrium price is around 100 dollars", according to the French Observatory of Economic Conjunctures (OFCE), the country has encouraged the fall of this price, which is first dropped below the \$ 80 mark in November 2014 to come down to $\$ 40$ in mid2015. Whatever the reason why Riyadh encouraged the decline in oil prices in mid-2014, this did not prevent the monarchy from making massive expenditures. The country's involvement in regional conflicts, its participation in the fight against the advance of the Islamic State and the taste of its population for luxury have been the source of massive spending, that the Saudi budget may not be able to balance. Whatever the outcome of this crisis, many experts believe that Saudi Arabia will have to step down on its hegemonic oil strategy. The Saudi government cannot remain the largest employer in the oil sector.

The role of religious tourism in sustainable development in Saudi Arabia: evidence from quantile non-causality test knowing that the United States became the largest oil producer in 2018, it can no longer rely on large infrastructure projects to grow its economy and it cannot continue to provide subsidies and make public spending. In 2017, Saudi Arabia's economic activity continued to slow due to low oil prices and production, as a result of the country's obligation to limit its production under OPEC agreements. The kingdom managed to reduce its budget deficit (a fall from $17.2 \%$ to $8.3 \%$ ) by drawing on 
its foreign exchange reserves and issuing bonds. The deficit should be financed by a decrease in assets and by domestic and international borrowing to a level of 1\% of GDP by 2022. The extent of this deficit reduction will depend on the implementation of the fiscal equilibrium program (non-oil revenue reforms) and a decrease in spending according to the resolutions of the Office of Rationalization of Expenditures. The kingdom has already reduced its subsidies on water, electricity and oil products, and introduces a value-added tax to reward the fall in oil prices. A vision shared by the International Monetary Fund (IMF), which advised the Kingdom to diversify its revenue sources and no longer rely exclusively on its oil resources in order to maintain an important growth rate.

In the framework of this thematic, our research makes the "'hajj" as an appropriate opportunity for promotion of economic growth and minimize the part of petroleum sector in GDP. We consider that a pilgrimage is a form of tourism.

Tugcu (2014) considers that the tourism has come to be the world 's fourth largest export industry after fuels, chemicals and food. The position of tourism in the world of total merchandise represents $6.8 \%$ from service export of international trade in service in the year 2017 (World trade Organization, 2018). Also, tourism represents in the average of $10 \%$ of the world of total GDP. Tourism is becoming increasingly important because the numbers of tourists are every year growing. These big numbers of tourists generate jobs and revenues. In this respect Saudi Arabia has a unique opportunity for having Mecca and Medina as source of religious tourism.

The objective of this research is to test the relationship between economic growth measured by GDPNP and tourism pilgrim or more principally tourism religion (hajj pilgrims) in Saudi using a quantile Granger non-causality test developed by Chuang et al. (2009). The causality-in-quantile approach is characterized by the following novelties: Initially, it is robust to misspecification errors by way of it detects the underlying dependence structure between the examined time series; this could prove to be particularly important, as it is well known that GDPNP displays nonlinear dynamics. Then, through this approach, we test for causality that may occur in the tails of the joint distribution of the variables, hence not only for causality in mean. To the best of our knowledge, this is the first study to employ a causality-in-quantiles approach to study the predictability of GDPNP based on numbers of pilgrims and trade ${ }^{1}$.

Using annual data for GDPNP of Saudi Arabia and the numbers of pilgrims over the period 1964 to 2017, we find empirical support for nonlinearity and regime changes between GDPNP and numbers of pilgrims, thus, corroborating the applicability of the quantile Granger non-causality test. Our findings show that the trade is a stronger predictor of GDPNP than numbers of pilgrims.

The rest of the paper is organized as follows. Section II surveys a literature review. Section III discusses the empirical methodology. Section IV presents data and the empirical results, and section $\mathrm{V}$ concludes.

\section{LITERATURE REVIEW}

Table 1 summarises the literature of the relationship between tourism and GDP, we notice that there are a contradictory findings in the nature and significance of this relationship. Some studies like Dubarry (2004), Dritsakis (2004), Lee \& Chang (2008) and Massidda \& Mattana (2013) have found a significant contribution of tourism receipts to both GDP and economic growth. Contrarians, Jin (2011) and Kouchi et al. (2016) did not confirm the long-run effect and causality between tourism and economic growth.

\footnotetext{
${ }^{1}$ As second source of GDP
} 
Table 1. Studies showing the relationship between tourism and economic growth

\begin{tabular}{|c|c|c|c|}
\hline Studies & Methods & Variables & Results \\
\hline Dubarry (2004) & $\begin{array}{l}\text { Cointegration and } \\
\text { causality }\end{array}$ & $\begin{array}{l}\text { GDP, physical capital, human } \\
\text { capital, real export of sugar, } \\
\text { manufactured exports, real } \\
\text { tourism receipts }\end{array}$ & $\begin{array}{l}\text { Existence of a causality } \\
\text { relationship }\end{array}$ \\
\hline $\begin{array}{l}\text { Dritsakis } \\
(2004)\end{array}$ & $\begin{array}{l}\text { Multivariate auto } \\
\text { regressive (VAR) and } \\
\text { Granger causality }\end{array}$ & $\begin{array}{l}\text { GDP, exchange rate, real tourism } \\
\text { receipts earnings }\end{array}$ & $\begin{array}{l}\text { Existence of a } \\
\text { bidirectional causal } \\
\text { relationship between } \\
\text { international tourism } \\
\text { and economic growth. }\end{array}$ \\
\hline $\begin{array}{l}\text { Lee \& Chang } \\
(2008)\end{array}$ & $\begin{array}{l}\text { Panel cointegration } \\
\text { and causality }\end{array}$ & $\begin{array}{l}\text { GDP per capita, real investment, } \\
\text { population and technologies } \\
\text { growth rates, capital } \\
\text { depreciation rate, international } \\
\text { tourism expenditure. }\end{array}$ & $\begin{array}{l}\text { Existence of a causality } \\
\text { relationship }\end{array}$ \\
\hline $\begin{array}{l}\text { Massidda \& } \\
\text { Mattana (2013) }\end{array}$ & SVECM & $\begin{array}{l}\text { GDP, tourism receipts, total } \\
\text { trade }\end{array}$ & $\begin{array}{l}\text { Tourism and trade } \\
\text { variables react rapidly to } \\
\text { real GDP shocks. }\end{array}$ \\
\hline Jin (2011) & $\begin{array}{l}\text { Impulse response } \\
\text { functions }\end{array}$ & $\begin{array}{l}\text { GDP, tourism receipts, exchange } \\
\text { rate, capital, labour, openness }\end{array}$ & $\begin{array}{l}\text { Only short run, but not } \\
\text { long-run. }\end{array}$ \\
\hline $\begin{array}{l}\text { Kouchi et al., } \\
\text { (2016) }\end{array}$ & ARDL-UECM & $\begin{array}{l}\text { Numbers of pilgrims, } \\
\text { Investment in Hajj sector, GDP }\end{array}$ & $\begin{array}{l}\text { Non-existence of long- } \\
\text { run Granger causality } \\
\text { among the variables }\end{array}$ \\
\hline $\begin{array}{l}\text { Hüseyni et al., } \\
\text { (2017) }\end{array}$ & Co-integration & GDP, tourism receipts & $\begin{array}{l}\text { Existence of a causality } \\
\text { relationship }\end{array}$ \\
\hline $\begin{array}{l}\text { Selimi et al. } \\
(2017)\end{array}$ & $\begin{array}{l}\text { panel regression } \\
\text { econometric } \\
\text { techniques }\end{array}$ & $\begin{array}{l}\text { income per capita, tourist } \\
\text { arrivals, tourism receipts, FDI } \\
\text { stock, exports and government } \\
\text { expenditures }\end{array}$ & $\begin{array}{l}\text { tourism has a positive } \\
\text { and significant impact } \\
\text { on economic growth in } \\
\text { the Western Balkan } \\
\text { countries }\end{array}$ \\
\hline $\begin{array}{l}\text { Suhel \& Bashir } \\
\text { (2018) }\end{array}$ & $\begin{array}{l}\text { Granger causality } \\
\text { model }\end{array}$ & $\begin{array}{l}\text { number of tourists, tourism } \\
\text { investment, government tourism } \\
\text { spending, and economic growth }\end{array}$ & $\begin{array}{l}\text { tourism sector affect } \\
\text { economic growth }\end{array}$ \\
\hline
\end{tabular}

Indeed, from an empirical perspective, Lanza and Pigliaru (2000) were the first to investigate the relationship between tourism and growth in some Islamic and non-Islamic countries. In 2004, Dritsakis (2004) studied the same hypothesis for the item of Greece between 1960 and 2000. By applying cointegration test suggested by Johansen and Granger's causality test the author proves the existence of relation of cointegration, then he applies an error-correction model, the author shows confirmation of a bidirectional causal relationship among international tourism and economic growth.

In addition to these studies, we can find a series of studies during 2010 and 2011 that analyses the same problem from different methodological perspectives. Taking again Turkey as a reference, Gocovali (2010) calculated the contribution of tourism to the economic growth of the country between 1985 and 2005 and their estimation of the elasticity of tourism was 0.53. Arslanturk et al. (2011), who also focused on Turkey, compared the results obtained by applying two different methodologies, because they believed in the need for taking into account the effects of certain factors, such as political or institutional changes, on the causal relationship between tourism and growth. Thus, the authors observed that, when they applied the error-correction model, the results indicated there was no causality between the series of variables. 
Following this line of analysis, Massidda and Mattana (2013) analysing the causality between tourism, trade and growth, and also shock transmission mechanisms. With this purpose in mind, they used a structural vector error model for the case of Italy. The findings revealed that tourism and trade variables respond quickly to real GDP shocks, nonetheless that a considerable longer time lapse is required for the real GDP to stabilize next a shock in the other two variables. During 2012 and early 2017, further works have been made for the intention of contributing further evidence to the verification of the TLG hypothesis. Among the studies which confirm the hypothesis, those by Arslanturk and Atan (2012) for Turkey, Tang \& Abosedra (2014) for Lebanon and Surugiu and Surugiu (2013) for Romania are particularly worth noticing, Ohlan (2017) for India, Shahzad et al.(2017) for China, France, Germany, Italy, Mexico, Russia, Spain, Turkey, the United Kingdom, and the United States.

Now, we investigate in the short reviews of literary research showing the economic aspect of Hajj that has been given less attention, and there is a pressing need to fill the gap. This section briefly concentrates on studies conducted about economic issues related to Hajj. Turner (1973) examined the influence of Hajj on Saudi Arabia's economic growth. In his research, he points to the essential nature of Hajj with the hardships and difficulties that pilgrims go through. He differentiates between tourism and pilgrimage and announces that it is hard to state that pilgrims seek the pleasure. By adding restraints, he reflected only pilgrims that picked to partake in Hajj voluntarily in his research of the role of Hajj in the economic growth of Saudi Arabia.

Cohen (1979) reflected Hajj along with its necessary rituals for pilgrims as a form of tourism and examined the role of Hajj in the economic growth of Saudi Arabia. Evidently, the question of whether one should reflect religious journeys to be in the same or a similar vein as tourism has been allocated with in research like Robinson (1972), in which visitors of sacred places in India and South Asia were measured as revenue resources for the economic growth of the countries they visited. In fact, Cohen's view was an implicit explanation of Nunez (1977), in which Mecca is presented as a unique tourism destination throughout diverse periods of time and considered Hajj as similar to a tourist journey.

Ascoura (2013) investigated in his paper the interaction between the evolution of pilgrims' numbers, the urban growth and problems arising during the pilgrimage season. He found that the residential areas has expanded outside the current tourism zone, therefore the urban development is being affected by the pilgrims activities.

Kouchi et al. (2016) studies the non-oil-based Gross Domestic Product (GDP) growth of Saudi Arabia as a function of the growing number of pilgrims and the investment growth in the Hajj sector. They apply the Vector Error Correction Model (VECM) to module the dynamics of the possible relationship between economic growth and the Hajj pilgrimage in KSA. The results of the study established the being of only one bidirectional Granger causal relationship between economic growth and the increasing number of Hajj pilgrims in short-term. But, the non-oil GDP of Saudi Arabia rises by o.84 Saudi Arabian Riyal ended the long-term in reply to a one-digit rise in the number of pilgrims. Manzo (2018) found that the total contribution of Travel \& Tourism to employment $^{2}$ was $1,116,500$ jobs in 2017 (9.1\% of total employment). This is forecast to raise by $0.6 \%$ in 2018 to $1,122,500$ jobs (8.9\% of total employment). Alotaibi (2018) investigates strategic planning in the hotel industry in the two holy cities of Makkah and Madinah concentrating in the provision of hotel accommodation for pilgrims during umrah and hajj. She confirms some of the general perceptions of the industry identified beforehand, and detect similarities and differences in marketing and strategic practices.

\footnotetext{
${ }^{2}$ Including wider effects from investment, the supply chain and induced income impacts.
} 


\section{METHODOLOGY}

We present in this section the recent methodology proposed by Chuang et al. (2009) to identify heterogeneity of Granger causality across diverse conditional quantiles. They suggested the Granger non-causality test in quantile range $[a, b] \subset(0,1)$. Remind that Lee and Yang (2006) considered only non-causality in a particular. The null hypothesis of this test is that a random variable in our study numbers of pilgrims ( Number of pilgrims ) does not Granger-cause another random variable non-oil-based Gross Domestic Product (GDPNP) in the $\tau-t h(\tau \in[a, b], 0 \prec \mathrm{a}, \mathrm{b} \prec 1)$ quantile. So, the null hypothesis can be written by Chuang et al. (2009) as:

$$
H_{0}^{Q 2}: Q_{G D P N P_{t}}\left(\tau / I_{t-1}^{G D P N P}, I_{t-1}^{\text {Numbers of pilgrims }}\right)=Q_{D P N P_{t}}\left(\tau / I_{t-1}^{G D P N P}\right)
$$

We note $Q_{G D P N P_{t}}\left(\tau / I_{t-1}\right)$ the $\tau$-th conditional quantile function of GDPNP given the information set $I_{t-1}=I_{t-1}^{G D P N P} \cup I_{t-1}^{\text {Numbers of pilgrims }}$ and $I_{t-1}^{G D P N P}$ and $I_{t-1}^{\text {Numbers of pilgrims }}$ are information setups to time t-1 generated by GDPNP $P_{t-1}$ and Number of pilgrims ${ }_{t-1}$ respectively. Knowing that $Q_{G D P N P_{t}}\left(\tau / I_{t-1}\right)$ is the linear conditional quantile function is written as:

$Q_{\text {GDPNP }_{i}}\left(\tau / I_{t-1}\right)=\alpha(\tau)+\sum_{i=1}^{p} \beta_{i}(\tau) G D P N P_{t-i}+\sum_{j=1}^{p} \gamma_{j}(\tau)$ Numbers of pilgrims $_{t-j} \tau \in[a, b](0 \prec \mathrm{a}, \mathrm{b} \prec 1)$

In that case the null hypothesis of (1) can be written as follows:

$$
H_{0}: \gamma(\tau)=0 \quad \tau \in[a, b] \quad(0 \prec \mathrm{a}, \mathrm{b} \prec 1)
$$

where $\gamma(\tau)=\left[\gamma_{1}(\tau), \ldots, \gamma_{q}(\tau)\right]^{\prime}$. This null hypothesis can be tested by a sup-Wald test. The Wald test statistic can be written as follows for a given fixed $\tau$ :

$$
W_{T}(\tau)=T \hat{\gamma}(\tau)^{\prime}\left(\Pi \hat{\Omega}(\tau) \Pi^{\prime}\right)^{-1} \hat{\gamma}(\tau) /[\tau(1-\tau)]
$$

wehre $\Omega(\tau)=D(\tau)^{-1} M_{X X} D(\tau)^{-1}, \hat{\Omega}(\tau)$ is the estimation of

$$
\Omega(\tau) \text {, }
$$

$X_{t-1}=\left[1, G D P N P_{t-1}, \ldots, G D P N P_{t-p}, \text { Numbers of pilgrims }_{t-1}, \ldots, \text { Numbers of pilgrims }_{t-q}\right]^{\prime}$,

$$
M_{X X}=T \rightarrow \infty \lim T^{-1} \sum_{t=1}^{T} X_{t-1} X_{t-1}^{\prime} \text { and }
$$

$D(\tau)=T \rightarrow \infty \lim T^{-1} \sum_{t=1}^{T} f_{t-1}\left(F^{-1}(\tau)\right) X_{t-1} X_{t-1}^{\prime}$. Such us the $F_{t-1}$ and $f_{t-1}$ are the

distribution and density function of $G_{t}$ conditional on $I_{t-1}$ and $T$ is the sample size.

In the practise, the sup-Wald test statistic can be calculated by partitioning $[a, b]$ with equal step as follow referring to Chuang et al. (2009): 


$$
\sup W_{T}=\sup _{i=1, \ldots, N} W_{T}\left(\tau_{i}\right), a \leq \tau_{1} \prec \ldots \prec \tau_{N} \leq b
$$

Where the $W_{T}$ is the Wald statistic, the $\tau_{i}$ is $i-t h$ particular quantile, In this empirical work we consider different quantile intervals $[a, b]$. The critical values for the asymptotic distribution of the sup-Wald test can be calculated by simulating the Brownian motion (Andrews (1993) and De Long (1981)). The result of the sup-Wald test on various $[a, b]$ may be used to identify the quantile range from which causality arises.

Koenker and Machado (1999) proved that the weak limit is the sum of squares of $\mathrm{q}$ independent Bessel processes. This immediately leads to the following result:

$$
\sup _{\tau \in[a, b[} W_{T} \stackrel{D}{\rightarrow} \sup _{\tau \in[a, b[}\left\|\frac{\mathrm{B}_{q}(\tau)}{\sqrt{\tau(1-\tau)}}\right\|^{2}
$$

where $\mathrm{B}_{q}(\tau)$ is a vector of q-independent Bessel processes.

\section{DATA ANALYSIS AND EMPIRICAL RESULTS \\ Data description}

This study uses annual data for the specified variables for Saudi Arabia from 1964 till 2017 to examine the impact of numbers of pilgrims on non-petroleum GDP. The data was collected from the World Bank World Development Indicators (World Bank, 2017); the World Investment Report (UNCTAD, 2017); and the IMF.

Table 2. Summary statistics

\begin{tabular}{|c|c|c|c|}
\hline & GDP-NP & Numbers of pilgrims & Trade \\
\hline Mean & 221499.345 & 1058249. & 77.29591 \\
\hline Average & 158892.194 & 995611.0 & 75.08284 \\
\hline Standard deviation & 242780.347 & 390287.0 & 12.57558 \\
\hline Skewness & 1.795 & 0.307532 & 0.769983 \\
\hline Kurtosis & 5.827 & 2.158656 & 4.094335 \\
\hline Minimum & 8057.920 & 374784.0 & 56.08838 \\
\hline Maximum & 1071535.080 & 1828195. & 120.6194 \\
\hline Jarque-Bera & $42.65971^{* * *}$ & 2.217582 & $7.286839^{* *}$ \\
\hline Probability & 0.000000 & 0.329958 & 0.026163 \\
\hline Observation & 49 & 49 & 49 \\
\hline
\end{tabular}

Notes: Jarque-Bera denotes Jarque and Bera's (1982) normality test. BDS (m, l) is the statistics for the linearity test of Brock et al. (1996), where $\mathrm{m}$ is the embedding dimension and $\mathrm{l}$ is the distance parameter. $\sigma$ is the standard error in the series. The numbers in the parentheses are p-values for the corresponding test statistics.

** denotes significance at the $5 \%$ level, ${ }^{* * *}$ denotes significance at the $1 \%$ level.

But the data for numbers of pilgrims was from annual reports of the Central Department of Statistics of Ministry of Economy and Planning of Saudi Arabia. Data reported in current price at point of collection have been converted into Year 2000 constant price by GDP deflator and scaled using natural logarithm. Table 2 summarizes the descriptive statistics for three variables: GDP-NP, Numbers of pilgrims and trade. All variables are skewed to the right, with excess kurtosis. The p-values for the normality test statistics confirm the non-normality distributions for both GDP-NP and trade. 
In table 3, we test the stationarity of the variables by conducting the Augmented Dickey-Fuller (ADF), Phillips-Perron (PP) and Kwiatkowski-Phillips-Schmidt-Shin (KPSS) unit root tests. The results obtained offer strong evidence that the null hypothesis of the unit root is not rejected, so all our variables are integrated of order one (i.e., I(1)). Nevertheless, all the variables are found to be stationary in the first difference and not in level. Since all variables in our study are integrated of order one only inflation and terms of trade, according to, at least, one of the tests employed. Clearly, the ADF, PP and KPSS tests reject the null hypothesis for, respectively, GDPNP (10\% level), Trade ( $5 \%$ level) and Number of pilgrims ( $1 \%$ level). Thus, the three variables are regarded as stationary series.

Table 3. Unit root test results

\begin{tabular}{|l|c|c|c|}
\hline & \multicolumn{1}{|c|}{ ADF } & PP & KPSS \\
\hline GDPNP & $-2.784295^{*}$ & -2.466323 & 0.286455 \\
\hline Numbers of pilgrims & -1.703928 & -1.676084 & $0.813084^{* * *}$ \\
\hline Trade & -1.98389 & $-2.967593^{* *}$ & 0.170558 \\
\hline & & & \\
\hline Critical values & & & 0.739000 \\
\hline $1 \%$ level & -3.577723 & -3.577723 & 0.463000 \\
\hline $5 \%$ level & -2.925169 & -2.925169 & 0.347000 \\
\hline 10\% level & -2.600656 & -2.600656 & \\
\hline \multicolumn{2}{|l|}{ Note: ${ }^{* * *}$ denotes significance at the 10\% level ${ }^{* *}$ denotes significance at the $5 \%$ level, } \\
\end{tabular}

\section{Empirical Result}

We started by testing the causal relationship using Granger causality test based on the following linear equations:

$$
\begin{aligned}
& G D P N P_{t}=\alpha_{0}+\sum_{i=1}^{p} \alpha_{i} G D P N P_{t-i}+\sum_{j=1}^{q} \gamma_{i} Z_{t-j}+\varepsilon_{G D P N P, t} \\
& Z_{t}=\beta_{0}+\sum_{i=1}^{p} \beta_{i} Z_{t-i}+\sum_{j=1}^{q} \varphi_{i} G D P N P_{t-j}+\varepsilon_{Z, t}
\end{aligned}
$$

where $Z_{t}=$ Number of pilgrims $_{\mathrm{t}}$ or Trade $_{t}$, GDPNP is the Gross Domestic Products Non Petroleum. We conduct a linear Granger causality test using VAR (1), the lag truncation orders is selected by using Akaike information criterion. The null hypothesis of the test is follow: $H_{0}^{m 2}: \varphi_{1}=\ldots=\varphi_{q}=0$ or $H_{0}^{m 1}: \gamma_{1}=\ldots=\gamma_{q}=0$, when the null hypothesis is rejected we indicate respectively that, $Z_{t}$ is said to Granger cause $G D P N P_{t}$ or $G D P N P_{t}$ is said to Granger cause $Z_{t}$.

The result reported in Table 4 proved that the null hypothesis of non-causality from numbers of pilgrims to GDPNP is rejected at the $5 \%$ significance level. However, in terms of trade, the same null hypothesis cannot be rejected even at the $10 \%$ significance level. In the opposite direction, the null hypothesis of non-causality from GDPNP to numbers of pilgrims or to trade cannot be rejected at 10\% significance level. Also, the null hypothesis of non-causality from trade to GDPNP cannot be rejected at $10 \%$ significance level. We recall that the linear Granger causality test can miss the important nonlinear causal 
relationship following to the sensitive of this test to non-normal or nonlinear series. Next, we test the presence of nonlinearity in the relationship between GDPNP and the two predictors, number of pilgrims and trade, by applying the Brock at al. (1996) test on residuals of an AR(1) model for GDPNP and the GDPNP equation in the VAR(1) model including number of pilgrims and trade. As illustrated in Table 5, the BDS test overwhelmingly rejects the null of non-iid structure for all of the embedding dimensions concerned, and hence, implies an omitted nonlinear structure.

Table 4. Linear Granger causality

\begin{tabular}{|l|c|c|}
\hline Null hypothesis & Statistic & p-value \\
\hline$G D P N P \rightarrow$ Trade & 0.924046 & 0.6300 \\
\hline Trade $\rightarrow$ GDPNP & 1.004667 & 0.6051 \\
\hline$G D P N P \rightarrow$ Numbers of pilgrims & 1.132492 & 0.5677 \\
\hline Numbers of pilgrims $\rightarrow$ GDPNP & $8.232944^{* *}$ & 0.0163 \\
\hline
\end{tabular}

** Significant at the $5 \%$ significance level.

Table 5. Brock et al. (1996) BDS test

\begin{tabular}{|l|c|c|c|c|c|}
\hline & \multicolumn{5}{|c|}{ Dimension } \\
\hline & 2 & 3 & 4 & 5 & 6 \\
\hline AR(1):GDPNP & 0.0000 & 0.0000 & 0.0000 & 0.0000 & 0.0000 \\
\hline $\begin{array}{l}\text { VAR(1):[GDPNP, } \\
\text { numbers of pilgrims] }\end{array}$ & 0.0100 & 0.0000 & 0.0000 & 0.0000 & 0.0000 \\
\hline VAR(1): [GDPNP, trade] & 0.0200 & 0.0000 & 0.0000 & 0.0000 & 0.0000 \\
\hline
\end{tabular}

Note: Entries correspond to the P-value of BDS test statistics applying to the residuals recovered from AR(1) model of GDPNP and the residuals from the GDPNP equation of the VAR(1) model with numbers of pilgrims or trade.

We also apply the Bai and Perron tests (2003) to AR(1) model for GDPNP and the GDPNP equation in the VAR(1) model including number of pilgrims and trade. This test is to detect a multiple structural breaks. The results presented in table 6 show the detection of four breaks for AR(1) model of GDPNP and seven breaks for VAR(1) model with number of pilgrims and trade. Given the evidence of structural breaks-points and nonlinear interdependencies, we next apply the quantile Granger non-causality test developed by Chuang et al. (2009), to deal with the misspecification of our linear model.

Table 6. Bai and Perron's (2003) test of multiple structural breaks

\begin{tabular}{|l|c|c|c|c|}
\hline \multicolumn{1}{|c|}{ Models } & \multicolumn{4}{c|}{ Break dates } \\
\hline AR(1):GDPNP & 1984 & 1975 & 1992 & 2000 \\
\hline VAR(1):[GDPNP, numbers of pilgrims] & 2001 & 2010 & & \\
\hline VAR(1): [GDPNP, trade] & 1979 & 1994 & 2010 &
\end{tabular}

Note: Break dates are based on the Bai Perron (2003) test of multiple structural breaks applied to the $\mathrm{AR}(1)$ and $\operatorname{VAR}(1)$.

Then, first, we study the causal relationship between Numbers of pilgrims and GDP-NP, by testing the Granger causality in quantiles. Resembling the test for linear causality, the quantile causality test is founded on the resulting conditional quantile functions:

$$
Q_{G D P N P_{t}}\left(\tau / I_{t-1}\right)=\alpha_{0}(\tau)+\sum_{i=1}^{q} \alpha_{i}(\tau) G D P N P_{t-i}+\sum_{j=1}^{q} \gamma_{j}(\tau) \text { Numbers of pilgrims }_{t-j}
$$




$$
Q_{\text {Numbers of pilgrims }_{t}}\left(\tau / I_{t-1}\right)=\beta_{0}(\tau)+\sum_{i=1}^{q} \beta_{i}(\tau) \text { Numbers of pilgrims }_{t-i}+\sum_{j=1}^{q} \gamma_{j}(\tau) \text { GDPNP }_{t-j}
$$

where $\tau \in[a, b](0 \prec \mathrm{a} \prec \mathrm{b} \prec 1)$. If the null hypothesis $H_{0}^{Q 1}: \gamma_{1}(\tau)=\ldots=\gamma_{q}(\tau)=0$ $(\tau \in[a, b])$ is rejected, $\left\{\right.$ Numbers of pilgrims $\left.{ }_{\mathrm{t}}\right\}$ is said to Granger-cause $\left\{\right.$ GDPNP $\left._{\mathrm{t}}\right\}$ in quantile interval $[\mathrm{a}, \mathrm{b}]$. If the null hypothesis $H_{0}^{Q 2}: \varphi_{1}(\tau)=\ldots=\varphi_{q}(\tau)=0$ $(\tau \in[a, b])$ is rejected, $\left\{\right.$ GDPNP $\left._{t}\right\}$ is said to Granger-cause $\left\{\right.$ Numbers of pilgrims $\left._{\mathrm{t}}\right\}$ in quantile interval $[a, b]$. Similar to Chuang et al. (2009), the same lag order q for both GDPNP $_{t}$ and Numbers of pilgrims $s_{t}$ is used. The lag order $q$ is selected when the supWald test is used. Let's say, if the null hypothesis $\gamma_{q}=0$ for $\tau \in[a, b]$ is not rejected under the lag-q model, however the null hypothesis $\gamma_{q} \neq 0$ for $\tau \in[a, b]$ is rejected for the lag-(q - 1) model, at that time we set the desired lag order $\mathrm{q}^{*}=\mathrm{q}-1$.

Additionally, the null hypothesis of $H_{0}^{Q 1}$ and $H_{0}^{Q 2}$ can be tested by the use of the sup-Wald test, as mentioned in second section.

In second time, we replace the Numbers of pilgrims by trade to test the relationship between trade and non-oil-based gross domestic product.

Table 7. Quantile causality test: Numbers of pilgrims and GDPNP

\begin{tabular}{|l|c|c|c|c|}
\hline \multirow{2}{*}{$\begin{array}{c}\text { Quantile } \\
\text { interval }\end{array}$} & \multicolumn{2}{|c|}{ Numbers of pilgrims / GDPNP } & \multicolumn{2}{c|}{ GDPNP / Numbers of pilgrims } \\
\cline { 2 - 5 } & Lag order & Statistic & Lag order & Statistic \\
\hline$[0.05,0.95]$ & 2 & $15.68^{* *}$ & 1 & 4.68 \\
\hline$[0.05,0.5]$ & 2 & 2.86 & 1 & 4.68 \\
\hline$[0.5,0.95]$ & 3 & $5.92^{*}$ & 2 & 3.24 \\
\hline$[0.05,0.2]$ & 1 & 3.56 & 2 & 0.86 \\
\hline$[0.2,0.4]$ & 1 & 3.74 & 1 & 4.68 \\
\hline$[0.4,0.6]$ & 1 & $5.72^{*}$ & 1 & 3.53 \\
\hline$[0.6,0.8]$ & 3 & $25.49^{* * *}$ & 1 & 2.56 \\
\hline$[0.8,0.95]$ & 2 & $26.68^{* * *}$ & 1 & 3.18 \\
\hline
\end{tabular}

Note: ${ }^{*}$ Significant at $10 \%$ significance level. ${ }^{* *}$ Significant at $5 \%$ significance level. ${ }^{* * *}$ Significant at $1 \%$ significance level.

Tables 7 summarizes the quantile causality test results for the causal relationship between the non-oil-based Gross Domestic Product (GDPNP $)_{t}$ and Numbers of pilgrims ( Numbers of pilgrims $s_{t}$ ).

First, for causality from the Numbers of pilgrims to GDPNP, the quantile causality test for the quantile interval $[0.05,0.95]$ is significant at the $5 \%$ significance level. The following test results in the sub-intervals further identify the quantile interval from which the causality arises. In particular, the quantile causality test is not significant for quantile intervals [0.05, 0.5] and [0.05, 0.2], but significant for quantile intervals $[0.5,0.95]$ and $[0.4,0.6]$ at the $5 \%$ significance level. In particular, it is significant for higher quantile intervals [0.6, 0.8] and [0.8, 0.95] at $1 \%$ level. 
It is generally believed that varying conditional quantiles of GDPNP reflects different prices situation; for example, high, medium, and low levels of quantiles correspond to expansionary, medium, and recessionary economic situation, respectively.

This is an important piece of information for political economics in Saudi Arabia. Indeed, the results imply that the numbers of pilgrims Granger-causes growth in a recessionary economic situation rather than an expansionary economic situation.

In opposite, in an expansionary economic situation, local pilgrims become pessimistic to make more expenses but the foreign pilgrims are neutral because they are forced to buy gifts for families and therefore spend.

These results are consistent with Kouchi et al. (2016). In the opposite direction, that is, from the non-oil-based Gross Domestic Product (GDPNP ${ }_{t}$ ) to ( Numbers of pilgrims $s_{t}$ ), the quantile causal relationships are non-significant for all quantile intervals, which is consistent with Balcilar et al. (2016) results.

Table 8. Quantile causality test: Trade and GDPNP

\begin{tabular}{|l|c|c|c|c|}
\hline \multirow{2}{*}{$\begin{array}{c}\text { Quantile } \\
\text { interval }\end{array}$} & \multicolumn{2}{|c|}{ Trade / GDPNP } & \multicolumn{2}{c|}{ GDPNP / Trade } \\
\cline { 2 - 5 } & Lag order & Statistic & Lag order & Statistic \\
\hline$[0.05,0.95]$ & 2 & $16.78^{* *}$ & 1 & 4.28 \\
\hline$[0.05,0.5]$ & 3 & $15.84^{* *}$ & 1 & 4.28 \\
\hline$[0.5,0.95]$ & 3 & $5.96^{*}$ & 2 & 3.34 \\
\hline$[0.05,0.2]$ & 1 & 3.946 & 2 & 0.96 \\
\hline$[0.2,0.4]$ & 1 & $5.84^{*}$ & 1 & 4.58 \\
\hline$[0.4,0.6]$ & 1 & $5.83^{*}$ & 1 & 3.53 \\
\hline$[0.6,0.8]$ & 3 & $16.39^{* *}$ & 1 & 2.42 \\
\hline$[0.8,0.95]$ & 2 & $17.53^{* *}$ & 1 & 3.15 \\
\hline
\end{tabular}

Note: ${ }^{*}$ Significant at $10 \%$ significance level. ${ }^{* *}$ Significant at $5 \%$ significance level. ${ }^{* * *}$ Significant at $1 \%$ significance level

Tables 8 summarizes the quantile causality test results for the causal relationship between the non-oil-based Gross Domestic Produc $\left(\right.$ GDPNP $\left._{t}\right)$ and Trade ( Trade $_{t}$ ). First, for causality from the Trade to GDPNP, the quantile causality test for the quantile intervals [0.05, 0.95] and [0.05, 0.5] and are significant at the 5\% significance level. In particular, the quantile causality test is not significant for quantile interval [0.05, 0.2], but significant for quantile intervals $[0.5,0.95]$ and $[0.4,0.6]$ at the $5 \%$ significance level.

In particular, it is significant for higher quantile intervals [0.6, o.8] and [0.8, 0.95] at $5 \%$ level. It is generally believed that varying conditional quantiles of GDPNP reflects different prices situation; for example, high, medium, and low levels of quantiles correspond to expansionary, medium, and recessionary economic situation, respectively. Indeed, that trade Granger causes growth rate in an extreme boom economic situation. In this state, agents may become loss aversion and herding behavior. In the low quantile levels of the level of trade, when agents are pessimistic, economic growth decrease.

\section{CONCLUSIONS}

In this study, we revise the predictability of religious tourism and trade for GDPNP using the causality-in-quantiles test of Chuang et al. (2009). Results show that the empirical evidence approves the presence of nonlinearity and regime changes 
relationship between trade or numbers of pilgrims and GDPNP. Next, we examine these causal relationships by conducting a quantile non-causality test (Chuang et al. 2009).

This test shows the existence of causal relationship from both the number of pilgrims to GDPNP and trade to GDPNP. Our study clearly shows that Saudi Arabia can enhance their economic growth and prospects by diversifying their economic activities through investment in the tourism industry principally in religious tourism, by moving further and further away from its traditional source of economic growth such as oil.

These findings suggest that Saudi Arabia should continue the efforts of maintaining a good level of investments towards the religious tourism industry and perhaps putting in place all the necessary strategies and financial resources and likewise to improve the performance of this industry. Therefore, Saudi Arabia needs to increase the number of their tourist arrivals (pilgrims).

\section{REFERENCES}

Alotaibi, H. (2018). Strategic Practices and Development of the Hotel Sector for Pilgrims in Makkah and Madinah. Working paper.

Arslanturk, Y. \& Atan, S. (2012). Dynamic relation between economic growth, foreigne xchange and tourism incomes: An econometric perspective on Turkey. Journal of Business, Economics \& Finance, 1(1), 30-37.

Arslanturk, Y., Balcilar, M., \& Ozdemir, Z. A. (2011). Time-varying linkages between tourism receipts and economic growth in a small open economy. Economic Modelling, 28, 664-671.

Ascoura, I.S. (2013). Impact of Pilgrimage (Hajj) on the Urban Growth of the Mecca. Journal of Educational and Social Research, Vol. 3 (2) May.

Bai, J. \& Perron, P. (2003), 'Computation and Analysis of Multiple Structural Change Models', Journal of Applied Econometrics, 18, 1-22.

Balaguer, J. \& Cantavella-Jordà, M. (2002). Tourism as a long-run economic growth factor: The Spanish case. Applied Economics, 34, 877-884.

Balcilar, M., Gupta, R., \& Pierdzioch, C. (2016). Does uncertainty move the gold price? New evidence from a nonparametric causality-in-quantiles test. Resources Policy, 49(1), 74- 80.

Barber, R. (1993). Pilgrimages. London: The Boydell Press.

Brock, W., D. Dechert, J. Scheinkman \& LeBaron, B. (1996), A Test for Independence Based on the Correlation Dimension. Econometric Reviews, 15, 197-235.

Chung, C-C. Kuan C-M. \& Lin H-Y. (2009). Causality in quantiles and dynamic stock return-volume relations. Tourism Management, 30(6): 812-8.

Cohen, E. (1979). A phenomenology of tourist experiences. Centre des hautes études touristiques.

De Long, D.M. (1981). Crossing probabilities for a square root boundary by a Bessel process. Communications in Statistics - Theory and Methods 10(21), 2197-2213.

Digance, J. (2003). Pilgrimage at contested sites. Annals of Tourism Research, 30(1), pp. 143-159.

Donald W. K. \& Andrews D. W. K. (2013). Tests for Parameter Instability and Structural Change with Unknown Change Point. Econometrica, Vol. 61, No. 4. (Jul.), pp. 821-856.

Dritsakis, N. (2004). Tourism as a long-run economic growth factor: An empirical investigation for Greece using causality analysis, Tourism Economics. 10(3), 305-316.

Dubarry, R. (2004). Tourism and Economic Growth: The Case of Mauritius. Tourism Economics 10 (4): 389401. Future Business Journal, Vol. 3 Iss. 1, p. 9-22.

Gocovali, U. (2010). Contribution of Tourism to economic growth in Turkey. An International Journal and Tourism and Hospitality Research, 21(1), 139-153.

Hüseyni, İ., Doru, Ö. \& Tunç, A. (2017). The effects of tourism revenues on economic growth in the context of neo-classical growth model: in the case of turkey. Ecoforum Journal, Vol 6, No 1.

Jin, J. C. (2011). The effects of tourism on economic growth in Hong Kong. Cornell Hospitality Quarterly, 52(3), 333-340.

Koenker, R. \& J. Machado. (1999). Goodness of fit and related inference processes for quantile regression. Journal of American Statistical Association, 94, 1296-1310. 
Kouchi, A. N., Nezhad. M. Z. \& Kiani. P. (2016). A study of the relationship between the growth in the number of Hajj pilgrims and economic growth in Saudi Arabia. Journal of Hospitality and Tourism Management, 1-5.

Lanza, A. \& Pigliaru, F. (2000). Tourism and economic growth: Does country's size matter? Rivista Internazionale di Scienze Economiche e Commerciali, 47, 77-85.

Lee, C. -C. \& Chang, C.P. (2008). Tourism development and economic growth: A closer look to panels. Tourism Management, V 29 (1), Februry, 180-192.

Lin, J., Li, J. \& Yang, J. (2006). The effect of audit committee performance on earnings quality. Managerial Auditing Journal, Vol. 21 No. 9, pp. 921-933.

Manzo, G.G. (2018). Travel \& tourism economic impact. The World Travel \& Tourism Council.

Massidda, C. \& Mattana, P. (2013). A SVECM analysis of the relationship between international tourism arrivals, GDP and trade in Italy. Journal of Travel Research, 52(1), 93-105.

Narayan, P.K., Narayan S., Prasad A. \& Prasad B.C. (2010). Tourism and economic growth: a panel data analysis for Pacific Island countries. Tourism Economics, 16(1): 169-183.

Nunez, T. (1977). Touristic studies in anthropological perspectives. In V. Smith (Ed.), Hosts and Guests: The Anthropology of Tourism. Philadelphia: University of Philadelphia Press, pp. 207-16.

Ohlan, R. (2017). The relationship between tourism, financial development and economic growth in India.

Robinson, G. W. S. (1972). The recreation geography of South Asia. The recreation geography of South Asia, V35, No.20, pp 139-144.

Selimi, N., Sadiku, M. \& Sadiku, L. (2017). The Impact of Tourism on Economic Growth in the Western Balkan Countries: An Empirical Analysis. International Journal of Business and Economic Sciences Applied Research, Vol. 10, Issue 2, June.

Shahzad, S.J.H., Shahbaz, M., Ferrer, R. \& Kumar, R.R. (2017). Tourism-led growth hypothesis in the top ten tourist destinations: New evidence using the quantile-on-quantile approach. Tourism Management, V6o, June, pp. 223-232.

Suhel S. \& Bashir, A. (2018). The role of tourism toward economic growth in the local economy. Economic Journal of Emerging Markets, 10(1), 32-39.

Surugiu, C. \& Surugiu, M. R. (2013). Is the tourism sector supportive of economic growth? Empirical evidence on Romanian tourism. Tourism Economics, 19(1), 115-132.

Tang, C. F. \& Abosedra, S. (2014). Small sample evidence on the tourism-led growth hypothesis in Lebanon. Current Issues in Tourism, 17:234-46.

Timothy, D. J. \& Olsen, D. H. (2006). Tourism, religion and spiritual journeys. London: Routledge.

Tugcu, C. T. 2014. Tourism and Economic Growth Nexus Revisited: A Panel Causality Analysis for the Case of the Mediterranean Region. Tourism Management 42 (6): 207-12.

Turner, V. (1973). The centre out there: The Pilgrim's Goal. History of Religions, 12(3). World Tourism

*** Organization (UNWTO). (2015). Why tourism? Available from (2015ed.) http://www2.unwto.org/ content/why-tourism (Accessed 10 November 15).

*** World trade Organization. (2018). World Trade Statistical Review.

Submitted:

05.07.2019
Revised:

16.12.2019
Accepted and published online 17.12.2019 